\title{
PENGARUH PERTUMBUHAN EKONOMI DAN INFLASI TERHADAP PENGANGGURAN TERBUKA DAN KEMISKINAN DI KOTA SAMARINDA
}

\author{
SitiAmalia \\ Fakultas Ekonomi Universitas Mulawarman Samarinda \\ E-mail: perpusmsi.unmul@gmail.com
}

\begin{abstract}
The purpose of this study was to determine the direct effect of economic growth and inflation against unemployment and poverty in Samarinda, to determine the direct effect of unemployment on poverty in Samarinda, and also the indirect effect of inflation on economic growth and poverty in Samarinda. Data analysis and hypothesis used in this study were path analysis method (Path Analysis Model). Based on the results of quantitative and qualitative analysis and hypothesis testing it can be generated the economic growth and inflation effect on unemployment in Samarinda. So that, government are expected to make better employment opportunities in order to reduce the number of unemployment in Samarinda.
\end{abstract}

Keywords: Direct Effect, Inflation, Economic Growth, Government, Samarinda

\begin{abstract}
Abstrak
Tujuan penelitian ini adalah mengetahui, (1) pengaruh langsung pertumbuhan ekonomi dan inflasi terhadap pengangguran terbuka dan kemiskinan di Kota Samarinda, (2) pengaruh langsung pengangguran terbuka terhadap kemiskinan di Kota Samarinda, dan (3) pengaruh tidak langsung pertumbuhan ekonomi dan inflasi terhadap kemiskinan di Kota Samarinda. Analisis data dan pengujian hipotesis dalam penelitian ini menggunakan metode analisis jalur (Path Analysis Model). Berdasarkan hasil analisis kuantitatif dan kualitatif serta hasil pengujian hipotesis dapat dihasilkan bahwa pertumbuhan ekonomi dan inflasi berpengaruh terhadap pengangguran terbuka di kota Samarinda. Sehingga diharapkan pada Pemerintah kota Samarinda lebih membuka peluang kesempatan kerja agar dapat mengurangi jumlah pengangguran terbuka di Kota samarinda.
\end{abstract}

Kata Kunci: Pengaruh langsung, Inflasi, Pertumbuhan Ekonomi, Pemerintah, Samarinda

Dalam konteks pembangunan ekonomi, kesempatan kerja dan kemiskinan merupakan masalah utama yang sangat penting untuk mendapatkan perhatian. Terjadinya kesenjangan antara permintaan dan penawaran tenaga kerja akan berakibat terjadi pengangguran dalam masyarakat yang berdampak sosial dan ekonomi seperti kemiskinan.
Mengembangkan kegiatan perekonomian dan memperluas kesempatan kerja serta menekan jumlah penduduk miskin tidak selalu akan dapat mewujudkan hasil yang diharapkan, terutama dalam menciptakan kesempatan kerja penuh "full employment" dalamperekonomiantanpa inflasi. Karenanya pemerintah di semua negara, terutama di nega- 
ra yang sedang berkembang selalu berupaya agar pengangguran yang terjadi dalam negara yang bersangkutan dapat ditekan pada tingkat full employment.

Dalam teori pertumbuhan ekonomi dijelaskan bahwa pertumbuhan ekonomi berkaitan erat dengan kenaikan output per kapita dan ada dua sisi yang perlu diperhatikan, yaitu output total (Gross Domestic Pro$d u c t$ ) di satu sisi, dan jumlah penduduk menganggur (tenaga kerja menganggur) dan penduduk miskin di sisi lainnya akibat terbatasnya lapangan pekerjaan dalam perekonomian.

Tenaga kerja yang menganggur sebenarnya merupakan persediaan faktor produksi yang dapat dikombinasikan dengan faktorfaktor produksi lain untuk meningkatkan output. Masalah pemanfaatan tenaga kerja yang menganggur ini menyangkut, baik penawaran maupun permintaantenaga kerja. Pandangan terhadap masalah ini banyak dibahas dalam literature Ekonomi Makro oleh para ekonom, di antaranya ekonom tersebut adalah J.M. Keynes, J.B. Say dan A.W. Phillips serta A. Okun.

Masalah kesempatan kerja sebenarnya merupakan satu dari beberapa masalah penting kependudukan yang oleh pemerintah selalu diupayakan pemecahannya, baik secara nasional maupun regional atau dalam wilayah tertentu. Perluasan kesempatan kerja dipandang sebagai cara terpenting untuk menyebarkan hasil-hasil pembangunan ekonomi secara lebih merata. Perluasan kesempatan kerja yang produktif akan meningkatkan produksi, sehingga dapat meratakan pendapatan dan partisipasi masyarakat dalam pembangunan. Sebaliknya ketidakmampuan dalam penyediaan kesempatan kerja akan menimbulkan persoalan tersendiri dalam pembangunan ekonomi.
Berdasarkan distribusi perkembangan penduduk miskin, dari tujuh kabupaten/kota dalam wilayahProvinsi Kalimantan Timur, Kota Samarinda masih mengalami kecenderungan peningkatan jumlah penduduk miskin, di samping Kabupaten Berau, Nunukan, Panajam Paser Utara, Tana Tidung, Kota Balikpapan, dan Bontang. Keadaan ini bila dibiarkan akan berdampak negatif pada lingkungan perkotaan, yang dalamEkonomiPerkotaan disebut sebagai "external economies" (Reksohadiprodjo dan Karseno, 2008: 119).

Laju pertumbuhan ekonomi Kota Samarinda dari tahun 2001 sampai dengan tahun 2011 berdasarkan harga konstan ratarata $6,60 \%$ dengan jumlah penduduk miskin 29.630 orang atau rata-rata $5,59 \%$, dan ini lebih rendah dari persentase rata-rata penduduk miskin Provinsi Kalimantan Timur, yaitu 9,42\% (Badan Pusat Statistik Kota Samarinda, 2011 [data diolah]. Meskipun demikian, upaya strategis dan terpadu mengurangitingkat pengangguran sekaligus jumlah penduduk miskin tersebut melalui kebijakan perluasan kesempatan kerja di berbagai sektor ekonomi masih dianggap relevan dan sangat penting dan mendesak dilakukan oleh Pemerintah Kota Samarinda.

Menurut beberapa penelitian di antaranya Akhmad Suprianto (2009), pengaruh Investasi dan Inflasi Terhadap Kemiskinan di Kota Samarinda. Hasil penelitian menunjukkan bahwa investasi swasta, investasi pemerintah dan Inflasi berpengaruh terhadap jumlah penduduk miskin di Kota Samarinda dalam kurun waktu tahun 2006 sampai dengan 2008, dan secara parsial investasi pemerintahberpengaruh dominanterhadap jumlah penduduk miskin di Kota Samarinda.

Amir (2007), pengaruh pertumbuhan ekonomi dan inflasi terhadap pengangguran di Indonesia, denganmenggunakan data peri- 
ode 1980-2005 menyimpulkan bahwa pertumbuhan ekonomi meningkat $1 \%$, maka pengangguran akan menurun sekitar $0.46 \%$, sedangkan Inflasi terbuktitidak ada pengaruh yang nyata terhadap penurunan jumlah penduduk miskin.

Kemiskinan merupakan kondisi absolut atau relatif, yaitu keadaan seseorang atau kelompok masyarakat dalam suatu wilayah karena sebab-sebab natural, kultural, atau struktural menyebabkan seseorang atau kelompok tersebut tidak mempunyai kemampuan untuk mencukupi kebutuhan dasarnya sesuai tata nilai atau norma tertentu yang berlaku dalam masyarakat (Nugroho dan Dahuri, 2012: 180). Dengan kata lain, seseorang atau kelompok masyarakat dikatakan miskin jika dan hanya jika tingkat pendapatannya tidak memungkinkan seseorang atau kelompok tersebut untuk mentaati tata nilai dan norma-norma dalam masyarakatnya. Jadi seseorang berada dalam kemiskinan bila penghasilannya, termasuk kekayaannya yang dinilai sekarang, lebih kecil daripada jumlah yang masyarakat pandang sebagai cukup. Cukup itu relatif karena pandangan masyarakat berubah-ubah.

Teori kesempatan kerja berkaitan langsung dengan angkatan kerja, penduduk yang bekerja dan tingkat pengangguran. Perluasan kesempatan kerja yang produktif akan meningkatkan produksi, sehingga dapat memeratakan pendapatan dan partisipasi masyarakat dalam pembangunan. Sebaliknya, ketidakmampuan dalam penyediaan kesempatan kerja akan menimbulkan persoalan tersendiri dalam pembangunan, seperti pengangguran. Perluasan kesempatan kerja dipandang sebagai cara terpenting untuk menyebarkan hasil-hasil pembangunan ekonomi secara lebih merata. Perluasan kesempatan kerja yang produktif akan meningkatkan produk- si, sehingga dapat meratakan pendapatan dan partisipasi masyarakat dalam pembangunan. Sebaliknya ketidakmampuan dalam penyediaan kesempatan kerja akan menimbulkan persoalan tersendiridalam pembangunan ekonomi.

Pertumbuhan ekonomi dapat didefinisikan sebagai suatu proses perubahan jangka panjang secara perlahan dan mantap yang terjadimelaluikenaikan dalam tabungan, produksi dan modal untuk meningkatkan output tanpa melihat apakah kenaikan output tersebut lebih besar atau lebih kecil dari tingkat pertumbuhan penduduk. Dalam teori pertumbuhan ekonomi, pertumbuhan ekonomi dapat menjelaskan kenaikan output per kapita dalam jangka panjang, seperti bagaimana faktor tersebut berinteraksi satu dengan yang lainnya, sehingga terjadi proses pertumbuhan. Jadi teori pertumbuhan ekonomi tidak lain adalah penjelasan logis mengenai bagaimana proses pertumbuhan ekonomi terjadi pada perekonomian suatu negara. Pertumbuhan ekonomi berkaitan erat dengnan kenaikan output per kapita dan ada dua sisi yang perlu diperhatikan, yaitu output total (Gross Domestic Product) di satu sisi, dan jumlah penduduk di sisi lainnya.

Pengangguran atau tuna karya adalah istilah untuk orang yang tidak bekerja sama sekali, sedang mencari kerja, bekerja kurang dari dua hari selama seminggu, atau seseorang yang sedang berusaha mendapatkan pekerjaan yang layak. Pengangguran umumnya disebabkan karena jumlah angkatan kerja atau para pencari kerja tidak sebanding dengan jumlah lapangan kerja yang ada yang mampu menyerapnya. Pengangguran seringkali menjadi masalah dalam perekonomian karena dengan adanya pengangguran, produktivitas dan pendapatan masyarakat akan berkurang sehingga dapat menyebabkan 
timbulnya kemiskinan dan masalah-masalah sosial lainnya.

Mengacu padadefinisikemiskinan, besarnya kemiskinan sebenarnya dapat diukur dengan tanpa mengacu pada garis kemiskinan (poverline). Dengan demikian, korelasiantara pertumbuhan ekonomi dan kemiskinan tidak berbeda dengan kasus pertumbuhan ekonomi dengan ketimpangan pendapatan. Mengikuti hipotesis Kuznets, pada tahap awal proses pembangunan tingkat kemiskinan cenderung meningkat dan pada saat mendekati tahap akhir pembangunan ekonomi, jumlah orang miskin berangsur-angsur berkurang. Namun banyak faktor lain selain pertumbuhan ekonomi yang juga mempengaruhi kemiskinan disuatu wilayah/Negara seperti struktur pendidikan tenaga kerja dan struktur ekonomi.

Untuk mendapatkan elastisitas bruto dari kemiskinan terhadap pertumbuhan ekonomi dan eklastisitas kemiskinan terhadap ketimpangan (pertumbuhan ekonomi sebagaivariabel yang dapat dikontrol) dapat digunakan persamaan:

$$
\begin{aligned}
& \log P k t=w+\log W k t+\log G k t+w k \\
& +v k t
\end{aligned}
$$

Dimana $\mathrm{P}_{\mathrm{kt}}$ adalahkemiskinan untuk wilayah $\mathrm{k}$ pada periode $\mathrm{t}$; $\mathrm{W}_{\mathrm{kt}}$ dan $\mathrm{G}_{\mathrm{kt}}$ seperti persamaan $\log \mathrm{G}_{\mathrm{kt}}=\alpha+\beta \log \mathrm{W}_{\mathrm{kt}}+\alpha_{\mathrm{k}}+$ $\Sigma_{\mathrm{kt}}$, di mana $\mathrm{G}_{\mathrm{kt}}$ adalah Index Gini untuk wilayah $\mathrm{k}$ pada periode $\mathrm{t} ; \mathrm{W}_{\mathrm{kt}}$ adalah tingkat rata-rata konsumsi (rasio kesejahteraan) di wilayah $\mathrm{k}$ pada periode $\mathrm{t} ; \alpha_{\mathrm{k}}$ adalah efekefek lokasi yang tetap (tidak berubah) atau acak (random); dan $\Sigma_{\mathrm{kt}}$ adalah faktor kesalahan (error terms).

Berdasarkan pembahasan di atas serta kajian teori yang telah dijelaskan maka penelitian ini bertujuan untuk Mengetahui pe- ngaruh langsung maupun tidak langsung pertumbuhan ekonomi dan inflasi terhadap pengangguran terbuka dan kemiskinan di Kota Samarinda.

\section{Metode Penelitian}

Operasionalisasi variabel dalam penelitian ini dilakukan untuk menjelaskan beberapa variabel penelitian yang dipilih, dan klasifikasi variabel yang digunakan. Yaitu VariabelEksogen: 1) Pertumbuhan ekonomi dalam penelitian ini adalah perubahan Produk Domestik Regional Bruto Kota Samarinda yang merupakan nilai tambah pendapatan dari tahun 2000 sampai dengan tahun 2011. Dalam penelitian ini variabel pertumbuhan ekonomi tersebut secara statistik dinyatakan dengan simbol $\mathrm{X}_{1}$ dengan satuan persentase $(\%)$; 2) Inflasi dalam penelitian ini adalah kenaikan harga umum secara terus menerus dan persisten dari perekonomian Kota Samarinda. Dengan indikator inflasi yang digunakan yaitu Perubahan Indeks harga Konsumen (IHK) atau yang biasa disebut sebagai indeks Biaya Hidup (IBH). Dalam penelitian ini variabel inflasi tersebut secara statistik dinyatakan dengan simbol $X_{2}$ dengan satuan persentase (\%). Variabel Endogen: 1) Pengangguran terbuka atau open unemployment dalam penelitian ini adalah pengangguran terbuka di Kota Samarinda, yaitu penduduk berusia lebih dari 15 tahun yang sedang mencari pekerjaan, atau yang mempersiapkan usaha atau yang tidak mencari pekerjaan karena merasa tidak mungkin mendapatkan pekerjaan (sebelumnya dikategorikan sebagai bukan angkatan kerja), dan yang sudah mempunya pekerjaan tetapi belum mulai bekerja (sebelumnya dikategorikan sebagai bekerja), dan pada waktu yang bersamaan orang tersebut tak bekerja (jobless). Dalam penelitian ini pengangguran terbuka 
secara statistik dinyatakan dengan simbol $Y_{1}$ dengan satuan jumlah orang dalam kategori menganggur; 2) Kemiskinan dalam penelitian ini adalah mengacu pada kriteria garis kemiskinan penduduk miskin versi Badan Pusat Statistik, yaitu penduduk yang memiliki ratarata pengeluaran per kapita per bulan $\mathrm{Rp}$ 233.740. yang umum digunakan di Indonesia yang ditetapkan pada bulan Maret 2011 untuk kemiskinan perkotaan, termasuk kemiskinan di Kota Samarinda. Dalam penelitian ini secara statistik dinyatakan dengan simbolY $Y_{2}$ dengan satuan jumlah orang dalam kategori miskin.

\section{Hasil Penelitian dan Pembahasan}

Dalam sub-bab ini analisis jalur (path analysis) yang telah dikonstruk diarahkan untuk menjelaskan hubungan kausalitas antara satu atau beberapa variabel terpilih yang telah dioperasionalkan dalampenelitian ini, sepertipertumbuhan ekonomi, tingkat inflasi, jumlah pengangguran terbuka dan jumlah penduduk miskin di Kota Samarinda.

Beberapa konstruk model jalur (path model) sebagai berikut; (1) Jalur kausal diberi simbol $\mathrm{X}_{1}$ dan $\mathrm{X}_{2}$, (2) Jalur kausal korelasi antara $X 1$ dan $X_{2}$, (3) Jalur kausal pertama pengaruh langsung dari $X_{1}$ dan $X_{2}$ memprediksi $Y_{1}$, (4) Jalur kausal kedua pengaruh langsung dari $\mathrm{X}_{1}, \mathrm{X}_{2}$ dan $\mathrm{Y}_{1}$ memprediksi $Y_{2}$, dan (5) Jalur kausal ketiga pe- ngaruh tidak langsung dari $X_{1}$ dan $X_{2}$ memprediksi $\mathrm{Y}_{2}$ melalui Y1.

Daribeberapa konstrukmodel jalur (path model) tersebut, analisis jalur langsung dan tidak langsung dalam analisis ini terlihat dari: a) Diagram anak panah setelah bergerak ke depan, jalur tidak dapat kembali ke belakang. Tetapi jalur tersebut dapat bergerak ke belakang berkali-kali sebelum digerakkan ke depan; b) Jalur tidak dapat bergerak menuju sebuah konstruk lebih dari satu kali; c) Jalur hanya dapat mencakup satu arah panah dua ujung, yaitu pasangan dari dua buah konstruk yang berkorelasi.

Berdasarkan prinsip-prinsip analisis jalur (path analysis) yang disajikan tersebut dan dengan menggunakan data yang telah dikumpulkan, didapatkan hasil analisis sebagai berikut: (1)Analisis atas uji kelayakan model (goodness of fit) yang menguji hipotesis nol yang menyatakan bahwa tidak terdapat perbedaan antara matriks kovarian data sampel dibandingkan dengan matriks kovarian populasi yang diestimasi. Nilai Chi-square statistic sebesar 2,59 (significance probability $=0,000)$ dengan Goodness - of- fit Index (GFI) sebesar 0,639<0,90; Adjusted Goodness-of-Fit Index (AGF) untuk Default model $(1,000)$ dan Default independence model $(0,399)<0,90$; Tucker Lewis Index (TLI) rho2 untuk Default model $(0,000)<0,95$, Comparative Fit Index (CFI) Default Model $(0,000)<0,95$; The

Tabel 1. Estimasi Parameter

\begin{tabular}{|c|c|c|c|c|c|}
\hline \multicolumn{6}{|c|}{ Regression Weights } \\
\hline & Estimate & S.E. & C.R. & $\mathrm{P}$ & Label \\
\hline $\mathrm{Y} 1 \leftarrow \mathrm{X} 1$ & -1240.574 & 851.632 & $-1,457$ & .145 & par_1 \\
\hline $\mathrm{Y} 1 \leftarrow \mathrm{X} 2$ & 517.962 & 530.579 & .976 & 329 & par_2 \\
\hline $\mathrm{Y} 2 \leftarrow \mathrm{Y} 1$ & -.600 & .247 & -2.431 & .015 & par_3 \\
\hline $\mathrm{Y} 2 \leftarrow \mathrm{X} 1$ & 1718.310 & 732.20 & -2.347 & 019 & par_4 \\
\hline $\mathrm{Y} 2 \leftarrow \mathrm{X} 2$ & -49.254 & 433.512 & -.114 & .910 & par_5 \\
\hline
\end{tabular}


Ekonomika-Bisnis Vol. 5 No.2 Bulan Juli Tahun 2014. Hal 173-182

Minimum Sample Discrepancy Function/ Degree of Freedom (CMIN/DF) untuk Default model $(2,253)>2,00$ dan The Root Mean Square Error of Approximation (RMSEA) Default model $(0,354)$ berada dalam rentang nilai diharapkan kecil dan karenaitu model ini dapat diterimakarena memiliki Goodness-of-fit yang baik. (2) Analisis signifikansi koefisien jalur (path coefficients) dilakukan melalui signifikansi besaran regression weights dari model dengan hasil seperti yang disajikan pada tabel 1 .

Berdasarkan hasil estimasi parameter seperti yang disajikan dalam Tabel 1 memperlihatkan bahwa semuajalur yang dianalisis menunjukkan adanya dua causal relationship yang signifikan, yaitu hubungan antara $Y 1$ dan Y2, dan hubungan antara X1 dan Y2. Sisanya tidak signifikan terlihat dari besaran koefisien jalur atau path coefficient estimate and standardized estimate dengan nilai CR yang lebih kecil dari 2,0 atau tingkat signifikansi uji hipotesis yang lebih kecil dari 0,001.

C.R atau Critic Ratio adalah identik dengan t-hitung dalam analisis regresi. Oleh KarenaItuC.R Yang LebihBesarDari2,0 Menunjukkan Bahwa Variabel-variabel itu secara signifikan merupakan dimensi dari faktor laten yang dibentuk terhadap regression weight yang dihasilkan oleh model. Hasil pengujian hipotesis tersebut secara sederhana dapat diringkas seperti yang terlihat pada Tabel 2 dan Tabel 3 .

Hasil pengujian hipotesis dalam bentuk diagram jalur (path diagram) disajikan dalam bentuk Gambar 1 .

Berdasarkan Tabel 2 dan Tabel 3 serta Gambar 1 diperoleh hasil pengujian hipotesis secara parsial masing-masing jalur langsung (direct effect) dan jalur tidak langsung (in-

Tabel 2. Hasil Pengujian Hipotesis Pengaruh Langsung

\begin{tabular}{cccc}
\hline $\begin{array}{c}\text { Variabel } \\
\text { Independen }\end{array}$ & $\begin{array}{c}\text { Variabel } \\
\text { Dependen }\end{array}$ & $\begin{array}{c}\text { Koefisien jalur } \\
\text { pengaruh langsung } \\
(\mathrm{p})\end{array}$ & Keputusan \\
\hline $\begin{array}{c}\text { Pertumbuhan } \\
\text { Ekonomi } \\
\text { Inflasi }\end{array}$ & $\begin{array}{c}\text { Pengangguran } \\
\text { Terbuka }\end{array}$ & -1240.574 & Non Signifikan \\
$\begin{array}{c}\text { Pengangguran } \\
\text { Terbuka }\end{array}$ & 517.962 & Non Signifikan \\
$\begin{array}{c}\text { Pengangguran } \\
\text { Terbuka }\end{array}$ & Kemiskinan & -.600 & Signifikan \\
$\begin{array}{c}\text { Pertumbuhan } \\
\text { Ekonomi } \\
\text { Inflasi }\end{array}$ & Kemiskinan & -49.54 & Signifikan \\
\hline
\end{tabular}

Tabel 3. Hasil Pengujian Hipotesis Pengaruh Tidak Langsung

\begin{tabular}{cccc}
\hline $\begin{array}{c}\text { Variabel } \\
\text { Independen }\end{array}$ & $\begin{array}{c}\text { Variabel } \\
\text { Dependen }\end{array}$ & $\begin{array}{c}\text { Koefisien jalur } \\
\text { pengaruh tidak } \\
\text { langsung }(\mathrm{p})\end{array}$ & Keputusan \\
\hline $\begin{array}{c}\text { Pertumbuhan } \\
\text { Ekonomi } \\
\text { Inflasi }\end{array}$ & Kemiskinan & 744.638 & Non Signifikan \\
\hline
\end{tabular}




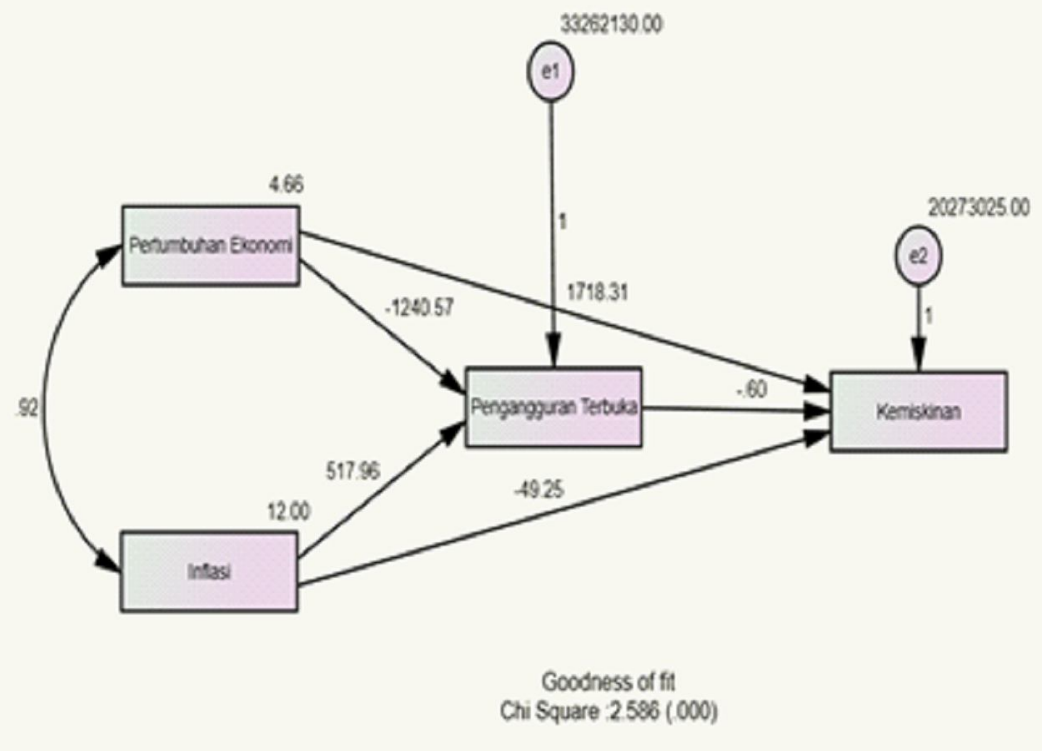

Gambar 1. Hasil Pengujian Hipotesis

direct effect) t-hitung pada Path Analysis yang direpresentasikan dengan $r$ value atau probability sebagai berikut:

Hipotesis 1 yang menyatakan bahwa pertumbuhan ekonomiberpengaruh langsung dan signifikan terhadap pengangguran terbuka di Kota Samarinda adalah ditolak. Berdasarkan analisis jalur, diperoleh koefisien jalur pengaruhlangsung pertumbuhan ekonomiterhadap pengangguranterbuka sebesar-1.240,574 dengan $r$ value atau probability 0,145 , memiliki tanda negatif dan tidak signifikan karena $\mathrm{r}$ value atau probability-nya lebih besar dari level of significance-nya. Hal ini mengandung arti bahwajika pertumbuhan ekonomi meningkat $1 \%$, maka akan diikuti secara langsung oleh penurunan jumlah pengangguran terbuka sebanyak 1.241 orang.

Hipotesis 2 yang menyatakan bahwa inflasi berpengaruh langsung dan signifikan terhadap pengangguran terbuka di Kota Samarinda adalahditolak. Berdasarkan analisis jalur, diperoleh koefisienjalur pengaruhlangsung inflasi terhadap pengangguran terbuka sebesar 517,962 dengan $\rho$ value atau probability
0,329, memilikitanda positifdan tidak signifikan karena $\rho$ value atau probability-nya lebih besar dari level of significance-nya. Hal inimengandung artibahwajikainflasimeningkat $1 \%$, maka akan diikuti secara langsung oleh peningkatan jumlah pengangguran terbuka sebanyak 518 orang.

Hipotesis 3 yang menyatakan bahwa pertumbuhan ekonomiberpengaruh langsung dan signifikan terhadap kemiskinan penduduk di Kota Samarinda adalah diterima. Berdasarkan analisis jalur, diperoleh koefisien jalur pengaruhlangsung pertumbuhanekonomi terhadap jumlah penduduk miskin sebesar $1.718,310$ dengan $\rho$ value atau probability 0,19 , memiliki tanda positif dan signifikan karena $\rho$ value atau probability-nya lebih kecil dari level of significance-nya. Hal ini mengandung arti bahwa jika pertumbuhan ekonomi meningkat $1 \%$, maka akan diikuti secara langsung oleh peningkatan jumlah penduduk miskin sebanyak 1.718 orang.

Hipotesis 4 yang menyatakan bahwa inflasi berpengaruh langsung dan signifikan terhadap kemiskinan penduduk di Kota Samarinda adalah ditolak. Berdasarkan analisis ja- 
lur, diperoleh koefisien jalur pengaruh langsung inflasi terhadap jumlah penduduk miskin sebesar -49,254 dengan r value atau probability 0,910 , memiliki tanda negatif dan tidak signifikan karena r value atau probability-nya lebih besar dari level of significance-nya. Hal ini mengandung arti bahwa jika inflasi meningkat $1 \%$, maka akan diikuti secara langsung oleh penurunan jumlah penduduk miskin sebanyak 49 orang.

Hipotesis 5 yang menyatakan bahwa pengangguran terbuka berpengaruh langsung dan signifikan terhadap kemiskinan penduduk di Kota Samarinda adalah diterima. Berdasarkan analisis jalur, diperoleh koefisien jalur pengaruh langsung pengangguran terbuka terhadap jumlah penduduk miskin sebesar -0,600 dengan $\mathrm{r}$ value atau probability 0,015 , memiliki tanda negatif dan signifikan karena r value atau probability-nya lebih kecil dari level of significance-nya. Hal ini mengandung arti bahwa jika pengangguran terbuka turun $1 \%$, maka akan diikuti secara langsung oleh penurunan jumlah penduduk miskin sebanyak $0,6 \%$.

Hipotesis 6 yang menyatakan bahwa pertumbuhan ekonomiberpengaruhtidak langsung dan signifikan terhadapkemiskinan penduduk di Kota Samarinda adalah diterima. Berdasarkan analisis jalur, diperoleh koefisien jalur pengaruh tidak langsung pertumbuhan ekonomi terhadap jumlah penduduk miskin sebesar 4,657 dengan $\mathrm{r}$ value atau probability 0,025 , memiliki tanda positif dan signifikan karena $\mathrm{r}$ value atau probability-nya lebih kecil dari level of significance-nya. Hal ini mengandung arti bahwa jika pertumbuhan ekonomi meningkat $1 \%$, maka akan diikuti secara tidak langsung oleh peningkatan jumlah penduduk miskin sebanyak 5 orang.

Hipotesis 7 yang menyatakan bahwa inflasi berpengaruh tidak langsung dan signifikan terhadap kemiskinan penduduk di Kota
Samarinda adalah diterima. Berdasarkan analisis jalur, diperoleh koefisien jalur pengaruh tidak langsung inflasi terhadap jumlah penduduk miskin sebesar 11,997 dengan r value atau probability 0,025 , memiliki tanda positif dan significance karena r value atau probability-nya lebih kecil dari level of significance-nya. Hal ini mengandung arti bahwa jika inflasi meningkat 1\%, maka akan diikuti secara tidak langsung oleh peningkatan jumlah penduduk miskin sebanyak $12 \%$.

Selanjutnya, untuk melengkapi hasil analisis dalam penelitian ini disajikan pula pengaruh total (total effect) hubungan antara variabel endogen dan eksogen sebagai berikut: 1. Pengaruhlangsung pertumbuhan ekonomi terhadap pengangguran terbuka adalah bertanda negatif, dan ini sesuai teori; 2. Pengaruh langsung inflasi terhadap pengangguran terbuka adalah bertanda positif, dan ini tidak sesuai teori; 3. Pengaruh tidak langsung pertumbuhan ekonomi terhadap jumlah penduduk miskin melalui pengangguran terbuka bertanda negatif, dan ini tidak sesuai teori; 4. Pengaruh tidak langsung inflasi terhadap jumlah penduduk miskin melalui pengangguran terbuka bertanda negatif, dan ini tidak sesuai teori.

\section{Penutup}

Berdasarkan hasil analisis kuantitatif dan kualitatif serta hasil pengujian hipotesis dan hasil pembahasan yang telah dilakukan, dapat disusun beberapa kesimpulan sebagai berikut: Pertumbuhan ekonomiberpengaruhlangsung terhadap pengangguran terbuka di Kota Samarinda. Inflasiberpengaruh langsung terhadap pengangguran terbuka di Kota Samarinda. Pengangguran terbuka berpengaruh langsung terhadap kemiskinan di Kota Samarinda. Pertumbuhan ekonomi berpengaruh langsung terhadap kemiskinan di Kota 
Pengaruh Pertumbuhan Ekonomi dan Inflasi Pengangguran Terbuka... (Siti Amalia)

Samarinda. Inflasiberpengaruh langsung dan tidak signifikan terhadap kemiskinan di Kota Samarinda Pertumbuhan ekonomi berpengaruh tidak langsung terhadap kemiskinan di Kota Samarinda. Inflasi berpengaruh tidak langsung dantidak signifikan terhadap kemiskinan di Kota Samarinda.

\section{DAFTAR PUSTAKA}

Anonim. 2011. Kalimantan Timur Dalam Angka. BPS-Bappeda Provinsi Kalimantan Timur.

Arsyad, Lincolin. 2005. Pengantar Perencanaan dan Pembangunan Daerah. BPFE-UGM. Yogyakarta.

Djojohadikusumo, S. 1994. Perkembangan Pemikiran Ekonomi: Dasar Teori Ekonomi Pertumbuhan dan Ekonomi Pembangunan. LP3ES. Jakarta.

Dornbusch et al. 2004. Macroeconomics. International. Published by McGrawHill/Irwin Inc. New York.

Ferdinand, Augusty. 2002. Structural Equation Modeling Dalam Penelitian Manajemen. BP-UNDIP. Semarang.

Fusfeld, Daniel Roland. 1994. The Age of The Economist. Harper Collins College Publishers. New York.

Gujarati, Damodar. 1995. Ekonometrika Dasar (Alih Bahasa Sumarno Zain. Erlangga. Jakarta.

Irawan dan Suparmoko. 2002. Ekonomika Pembangunan. BPFE. Yogyakarta.

Kosasih, Sri. 2011. Pengaruh Pertumbuhan Ekonomi dan Upah Serta Inflasi Terhadap Tingkat Pengangguran di Kota Samarinda. Tesis EPP, Fakultas
Ekonomi, Universitas Mulawarman, Samarinda.

Nugroho, Iwan dan Rokhmin Dahuri. 2012. Pembangunan Wilayah: Perspektif Ekonomi, Sosial dan Lingkungan. LP3ES. Jakarta.

Setiono, Dedi N.S. 2011. Ekonomi Pengembangan Wilayah: Teori dan Analisis. LPFE-UI. Jakarta.

Suprianto Akhmad. 2009. Pengaruh Investasi dan Inflasi Terhadap Kemiskinan di Kota Samarinda. Tesis EPP, Fakultas Ekonomi, Universitas Mulawarman, Samarinda.

Tambunan, Tulus T.H. 2001. Perekonomian Indonesia: Teori dan Temuan Empiris. LP3ES. Jakarta.

Todaro, Michael dan Stephen C. Smith. 2004. Pembangunan Ekonomi di Dunia Ketiga (Alih Bahasa Haris Munandar dan PujiA.L.). Erlangga. Jakarta. 
